\title{
Students' Academic Identities in Time of Uncertainties
}

\author{
Ninuk Krismanti
}

\author{
STKIP PGRI Banjarmasin \\ ninukkrismanti@stkipbjm.ac.id
}

\begin{abstract}
This narrative inquiry is set to investigate how ELESP students enrolled in the pandemic era construct their academic identities and what possibly influences the deconstruction of these identities. This study involves five participants. The participating students are the ones enrolled as university students at time of pandemic; therefore, their way of seeing themselves as students may be different as they are yet to experience the traditional sit-in-the-class teaching and learning activities at university level. The data are collected through semi-structured interviews. The results of this study show that students' academic identities are constructed by the awareness of their future aspirations, active classroom participation, and supportive interactions among members of academic groups. The shifting from offline to online learning that comes with various technical issues does not make students down nor negatively affects their learning motivation. In other words, students' academic identities are not easily deconstructed because of the pandemic. The students negotiate their identities with the situation positively.
\end{abstract}

Keywords: Identities, Students, Pandemic, Narrative.

\section{INTRODUCTION}

Knowing who we are and why we belong to certain communities matter. Therefore, it is not surprising that issues related to students' identities have become one of flourishing topics in the context of language learning all over the world. Identities are related to the sense of belonging and the sense of realizing why we are involved in certain social groups. In relation to education, students' identities as part of an academic community are highly influential to their achievements. Students who are aware of their purpose of studying and know what they want to be in the future are more likely to perform better in their class.

Identities are often contradictory in the way that they make us question why they are different from others. Identities are always multiple in nature, meaning that we can have more than one belief, value, and trait all at once. Identities are continually reshaped and reconstructed due to self-perspective and external reasons. To understand the identities of someone, Norton [1] said that we need to recognize one's investment. In relation to students' identities, investment consists of students' instrumental motivation, integrative motivation, social history, and desires that are intertwined in the process of constructing, deconstructing, and reconstructing identities.
Because the study on identities enables us to understand the students in a better perspective, the researcher was willing to explore students' academic identities in this time where the changing in education has been dramatic due to pandemic. To meet the nature of narrative inquiry where personal experiences are seriously taken, this study was set at STKIP PGRI Banjarmasin where the researcher was academically involved as one of the lecturers and shared personal experiences with all the students participating in this study.

\section{LITERATURE REVIEW}

\subsection{Related Research}

In the context of Indonesia, the exploration of students' identities has been conducted by several researchers. Wijaya \& Mbato [2] and Triutami \& Mbato [3] are among those interested in investigating identities of students majoring in English. Wijaya \& Mbato [2] explored students' perceptions towards their identities as future EFL teachers. They focused their study on factors influencing students' identities construction. This study revealed that massive and continuous support such as meaningful feedback affected students' identities construction. Triutami \& Mbato [2] focused their study on how students developed their professional identities. This study 
revealed that students' identity construction was a dynamic process affected by three factors: students' self-perception, academic environment, and teaching practices.

To compare their investigations with this study, the researcher outlined at least two aspects. The first one was the focus of the study. Although the two previous studies were set to analyze students' identities, the focus was different when compared to the one in this study. Unlike the two previous studies that focused on students' professional identities construction as later-tobe EFL teachers, this study was intended to explore students' academic identities. The second comparison was observable through the methodology used. Wijaya \& Mbato (2020) mentioned that qualitative approach was employed as their method without specifically classified the design further; Moreover, Triutami \& Mbato (2021) stated that their research was a case study under qualitative paradigm. On the contrary, this research was carried out by applying narrative inquiry that reconstructed the details of the stories of participants to present the findings and draw research conclusions.

\subsection{Identities}

Identity sounds familiar but not always easy to define. Djite [4] defined identities as the term used by someone to make sense of 'who they are'. Stets \& Burke [5] stated that identity is related to distinctive meaning and position someone possesses to be a member of one social group. How someone feels regarding the meaning of his group and his role in the group are dynamic. Identities are about the notion of how members of certain groups share similarities and what makes them different from other people of different groups.

Academic identities deal with how students perceive themselves as a part of an academic setting. Dunham [6] defined academic identities as the way students see and practice academic values as reflected in their commitment and eagerness to engage in academic activities. Identities are always personal; therefore, they are highly related to theories of self. Self-theories come from knowledge someone obtains within himself and from the surrounding. In academic context, self-theories underline how students compare themselves with other students and how they are motivated to participate in the classroom. Students' academic experiences are always emotional; they are intertwined with students' selfesteem which can be either high or low.

In the perspective of post-structuralism, Kroskrity [7] indicated that language is the means by which people construct their memberships. Language enables us to talk about, negotiate, and reshape identities. In short, identities are temporal and continually changing. This is in line with Larsen-Freeman \& Cameron [8] who state that the construction of identity through the use of language is not static in nature.

\subsection{Narrative Inquiry}

Creswell [9] mentioned that a narrative study emphasizes personal stories told in forms of texts or conversations. In the education field, narrative inquiry is first introduced by Connelly and Clandinin [10] as a method to narrate personal experiences of teachers. In narrative study, words uttered by the participants of the study are analyzed to develop holistic stories to uncover the matters being investigated.

Narrative inquiry is useful for at least three reasons. First, it promotes the comprehension of how human beings live in social context. Second, it helps us reflect on our past experiences to give lessons for personal and professional growth. Lastly, it enables us to connect one detail to another to create a bigger picture on the investigated matters. This methodology makes it possible for researchers to explore experience deeply by the use of stories being narrated as data.

Trahar [11] argued that through narrative inquiry, the voices that used to be silenced or overlooked can be amplified. Experience is the best teacher. Hearing stories and making meaning out of the messages behind the stories are useful tools to understand something better. The main goal of narrative approach is neither to categorize data nor to make generalization; instead, it respects and acknowledges experiences to be dynamic in nature. The stories in narrative inquiry are places for participants to voice their experiences without being afraid of external pressure.

\section{METHODOLOGY}

\subsection{Design}

This research was an attempt to explore students' stories with the intention to reveal their academic identities. Because the data of this research were in the form of stories being told by the students, narrative inquiry was employed in this study. Narrative inquiry as mentioned by Clandinin and Rosiek [12] focuses on individual as well as social, cultural, and institutional factors underlying the construction, expression, and practice. Through this design, the researcher aimed to reconstruct students' identities and narrate them to create understanding on how the students construct their academic identities and to reveal factors contributing to the deconstruction of these identities. 


\subsection{Participants}

This study involved five participants enrolled as second year students in ELESP of STKIP PGRI Banjarmasin. The reason why they were chosen was because since the first day of their university time, they had been affected by the pandemics, causing them not to be able to attend traditional sit-in-classroom learning. Therefore, the construction and deconstruction of academic identities might be different from senior year students. The five participants were labeled S1, S2, S3, $\mathrm{S} 4$, and S5 to keep their personal information credential.

\subsection{Data Collecting Procedures}

The data of this study were stories obtained through semi-structured interviews. Stories are connected to our identities and values because the language that we use represents who we are [13]. Before collecting students' stories, all participants were informed about the objective of this study. This information was necessary to scope participants' answers during the interview. The interview was done separately so that participants' answers were not influenced by the answers of others. Furthermore, the credential of the participants could be guaranteed. Because of the pandemic, the interview was conducted via voice call. The data were recorded for further analysis. In the process of data collecting, the participants were allowed to make emphasis on what they believed to be important in the stories being told.

\subsection{Data Analysis}

For the purpose of data analysis, the interview was narrated to outline personal and social factors contributing to their identities' construction and deconstruction. The data then analyzed using three dimensions of narrative inquiry based on Connelly \& Clandinin [14] namely temporality, interaction, and situation. Temporality deals with the reshaping of students' identities before and after becoming part of ELESP of STKIP PGRI Banjarmasin. Interaction deals with the negotiation of students' identities in relation to internal and external situations. Situation deals with the influence of learning settings in constructing and deconstructing students' identities.

\section{FINDINGS AND DISCUSSION}

\subsection{Backgrounds of Participated Students}

The five participants in this study were enrolled in ELESP of STKIP PGRI Banjarmasin in 2020. All of them were among the students who had been forced by the Covid-19 situation to study from home. Therefore, they were yet to experience traditional come-to-classhang-out-with-fellow students-after that once was common for most university students. The participating students came from different regions of South and Central Kalimantan. They agreed to participate in this study and were well-informed about the purpose of the study.

S1 was 19 years old. He was born in Kandui and currently lives in Buntok. He stated that enrolling as an ELESP student of STKIP PGRI Banjarmasin was his own decision. His interest in learning English had been growing since he was a kid. He mentioned how he always loved English and wanted to teach the language in the future. He realized his position as part of ELESP of STKIP PGRI Banjarmasin because of his intense communication with other ELESP members.

S2 was 17 years old. She was born in Banjarmasin and had been living in this town ever since. She chose to study at ELESP of STKIP PGRI Banjarmasin by her own decision. She admitted that she was a shy person who often faced difficulties in socializing with her fellow students. She also acknowledged her passiveness in the classroom due to this personality trait. She realized her position as a member of ELESP because she had been choosing to be a student of this program and had been consciously putting efforts in fulfilling her role in this academic community.

S3 was 19 years old. He was born in Banjarmasin and currently lives in Puruk Cahu. He said becoming a member of ELESP of STKIP PGRI Banjarmasin was his own decision. This decision as he mentioned was motivated by his dream to be able to talk with foreigners fluently someday. He claimed that his realization of his position as a member of ELESP came from the fact that he was still registered as a student in this department.

S4 was 19 years old. She lived in Martapura. She said enrolling as a student of ELESP of STKIP PGRI Banjarmasin was her own decision. She wished to have more opportunities in learning English in this department because she perceived the English classes she experienced during her senior high school years as too textbook-oriented classes. She claimed herself as a regular student who did not invest time in extracurricular activities for her health condition. Her realization as the member of the ELESP came from the fact that she had just finished her second semester in this program and would soon continue to the third semester.

S5 was 20 years old. She was born in Tanjung Dewa and now resided in Banjarmasin. Her decision to be a student of ELESP of STKIP PGRI Banjarmasin was made on her own because she followed the suggestion of her neighbor. She realized her role as the student of ELESP because of the targets she had set for herself regarding her study. 


\subsection{Imagined Academic Community, Current Reality, and Imagined Future}

In studying identities, participants' imaginations are often taken as data. Block [15] stated that identities can be considered as the narratives that are constructed socially, consciously, and continually as one does, makes meaning, and pictures the future. In this sense, how we project the future narrates the identities that we have constructed.

The concept of 'imagined identities' was made popular by Norton \& Toohey in 2011 [16]. Our imagination of the future accommodates our personal and social experiences; in other words, our imagination reflects our identities. This is also in line with Wenger [17] who agreed on the importance of imagination when thinking about our position as a social group member. Imagination is needed to make us aware of the sense of self and to enable us to make interpretation toward our participation in the group. Furthermore, Kanno and Norton [18] argued that to understand identities, our investments in the expected or imagined world must be understood along with our real investments.

In relation to this research, imagination was used to explore students' expectations before becoming ELESP students and the future aspirations they had in relation to their current status as students. These imaginations narrated into stories were useful in the attempt to explore students' academic identities.

Prior to studying at STKIP PGRI Banjarmasin, students had constructed their imaginary academic communities in their minds. S1 had imagined that by becoming a student of ELESP, his days would be highly exposed by English. However, the reality was not always like that. The exposure of English was not as he expected. Indonesian and even Banjarese were still highly used in the classroom interactions. Local language and Indonesian language were also more dominant in the interactions among ELESP students. Fortunately, classroom interactions made via Zoom or Google Meet still provided room for frequent English usage.

Unlike S1 who had a positive imagination on ELESP prior to their enrollment, S2 had imagined that university days would be busy and stressful. This imagination was formed because her cousins told her the hectic and full-of-pressure sides of being a university student. However, she found the reality to be a total opposite of what she had pictured in mind. Her time as a college student was not hard since she received academic and personal support from her friends and lecturers.
What S3 had imagined about being an ELESP student was exactly similar to what he experienced so far. He was able to learn English more seriously. Furthermore, the environment was supportive and made him learn the language well. He also learned to teach the language for other people in this major - as what he expected before. However, he never thought that his accent would hinder him from speaking like a native. His mother tongue, Dayakese language, made him feel somewhat difficult to learn English pronunciation.

S4 was the only student who claimed that she had not set any expectation or imagination regarding her university time. She chose to go with the flow and just accepted whatever provided in front of her. However, she said she was still grateful over her decision to study in this institution.

Unlike S4 who did not have any imagination toward the academic environment prior to her enrollment, S5 had pictured her time as a university student as a super busy one. She had imagined meeting many people, getting involved in hundreds of activities, and having hectic days. However, in reality, she stayed home and learned distantly from other class members because of the pandemic.

Students' academic identities at the time being were always related to how they portray themselves in the future in relation to their position right now as students. S1 imagined that in the future he would be able to teach English, travel the world, and become a photographer. S2 did not project her future too far as all she wanted was to be less shy and more active in the classroom later. S3, S4, and S5 shared a similar imagined future in which they would become professional teachers later. S3 further explained that he wanted to change the mindset of 'English is difficult to learn' by applying what he got during his study time at STKIP PGRI Banjarmasin. He believed that a good teacher could change how students perceived something.

\subsection{Students' Participation in Classroom}

In terms of classroom participation, students' experiences were varied. S1 considered his participation in the classroom as his way of respecting the lecturers. Thus, he tried to follow all classes actively on any platform. S2, on the other hand, admitted that she was lacking in the classroom participation because of her shy personality. Despite being passive in the classroom, S2 knew her responsibility as a student and always did her tasks on time and occasionally voiced her opinions when asked by the lecturers. S2 was fully aware of her character and wanted to be more enthusiastic and active in the following semesters. She planned to take more initiations in the classroom and to make more friends. 
By doing so, she believed she would feel less out-casted and could achieve her academic goals better.

S3 tried to participate in the classroom by trying to join all classes via Zoom, Google Meet, or other platforms although he often experienced issues with his internet connection. The internet connection in his place was so problematic that he hoped the authorities could fix this soon. His effort in joining the class despite the technical issues was his way of participating actively in the class even though he rarely spoke during the learning process unless being asked.

S4 and S5 claimed that they did not have problems with their classroom participation. They shared similar thoughts that they realized their goals in learning English and they had to study hard to achieve the goals. Therefore, they claimed their participation as active participation and they did not hesitate to ask the lecturers or friends if they did not understand the materials.

\subsection{In-class and Out-class Interaction}

Becoming a member of an institution means that the students have to interact with other members. Academic interaction is powerful to help students shape their identities. In terms of interaction, S1 stated that he could interact well with lecturers and fellow students although they could not physically meet. Technology made it possible for him to interact with others during the quarantine days. The interactions he made with other members of ELESP gave him motivation in studying. He was grateful that the classroom interactions run well for lecturers' flexible and friendly ways of communication.

$\mathrm{S} 2$ believed that the interactions she made so far in the academic settings made her comfortable. She considered good interactions that she had as valuable resources for her to keep being motivated as a student. This is in line with what S3, S4, and S5 felt about their academic interactions. Furthermore, S5 claimed that the interactions among students and lecturers in the classroom inspired her to learn more. When she thought her friends performed better in the classroom, she was motivated to do the same that she worked for.

\subsection{Negotiating Identities during Online Learning}

The situation right now has left Indonesian schools with no choice than shifting the process of teaching and learning into online classes. Students who were studying in college ten years ago probably would experience their university years and construct their academic identities in different ways than the pandemic-affected students.
In this matter, $\mathrm{S} 1$ felt that online learning caused him to stay connected with his mobile phone and laptop for a long time. This was because he did not want to miss any information regarding his study. On the bright side, online learning enabled him to stay home and helped his parents. It was also more cost efficient as he did not need to pay for rent and transportation expenses.

Instead of hating online learning, S2 felt that online learning was effective as she was able to browse materials that she did not understand while listening to the lectures. However, she was aware of the physical tiredness caused by online learning. Staring at the screen for a long time made her eyes tired and in turn, it would disturb her focus in the class.

S3 felt that the lectures could still run well even in online learning as the lecturers and students put effort in making the process of teaching and learning run well. However, he hated the fact that sometimes his strong willingness to learn was disturbed by unstable connections. Other than the internet stability, he did not find the online learning system problematic and ineffective.

On online learning, S4 extended her worries. For her, online learning made students' focus easy to be distracted. This was because the gadget and internet connection that they used to join the class could also be used to browse other things. This was not the case of offline learning where students' interaction with their gadgets was limited so that they could keep their focus on the lectures.

On the other hand, S5 believed that her online learning promoted positive things for her. She claimed to be a more independent learner after the era of online classes. Furthermore, she also felt that she benefited with the easy access and time flexibility during online learning. She could browse the information needed to help her understanding and could revisit the materials posted by the lecturers any time. However, the issue in connection made her sometimes lose her mood in studying because once her connection was problematic, she felt that she could not catch up with her friends and this frustrated her.

\subsection{Further Discussion}

A further discussion for this study was arranged based on the three dimensions of narrative inquiry as stated in the methodology. In the dimension of temporality, all participated students agreed that becoming students of ELESP had changed them personally and academically. Personally, they were more aware of responsibilities regarding their study. As being the ELESP students was their own choice and 
they had targets to achieve, they were motivated to learn seriously in this program. Academically, the students realized that because their major was English, the materials offered in their programs would enable them to learn English from basic level to advanced level. They realized that the lessons taught would be gradually set to higher levels. Therefore, when they wanted to achieve high proficiency, they had to take learning seriously.

In terms of dimension of interaction, it was concluded that the interactions between academic members of ELESP led to a positive impact in students' motivation. Lecturers and students' meaningful participation in the classroom shaped students' positivity as parts of the community. Furthermore, In terms of dimension of settings, online learning did not always negatively affect students' learning process negatively. In spite of facing issues during the online process, the students still tried to get involved in the classroom actively. Also, their motivation in learning was not shaken simply because they could not attend the class on site. The students knew what they aimed for and why they were studying at ELESP; therefore, how the teaching and learning process was conducted did not really bother them.

\section{CONCLUSION}

Conclusions drawn based on the results of the study are as follows:

1. Internal factors that contribute to the construction of students' academic identities include students' future aspirations and their willingness to improve themselves academically.

2. External factors that contribute to the construction of students' academic identities include support from other members of ELESP and positive competition among fellow students.

3. Issues occurring in relation to online learning cause problems to students but do not greatly affect their motivation in learning as their support system works.

4. Students negotiate their identities in the pandemic situation by taking the light side of the pandemic instead of focusing on the drawbacks.

\section{REFERENCES}

[1] B. Norton, Identity and language learning: gender, ethnicity, and educational change, Harlow: Pearson Education, 2000.

[2] K. Wijaya and C. Mbato, "Undergraduate Students' Perceptions on their Identity as Future EFL Teachers, in: Proceedings of Journal of English Teaching, vol. 6, no. 2, 2020, pp. 96-110, 2020.

[3] C. Triutami, C. Mbato, EFL Undergraduate Students' Professional Identity Construction: A Sociocultural Perspective, in: Proceedings of Journal of English Education and Teaching (JEET),vol. 5, no. 1, 2021, pp. 1-15.

[4] P. G. Djité, Shifts in linguistic identities in a global world, in: Proceedings of Language Problems \& Language Planning, vol. 30 , no. 1, 2006, pp. 1-20.

[5] J. Stets and P. Burke, A sociological approach to self and identity, in Handbook of self and identity, 2005, p. 128-152.

[6] N. Durham, Student academic identity and early childhood field-based initial teacher education, in: Proceedings of AARE Conference 2016, 2016.

[7] P. V. Kroskrity, Identity, in: Proceedings of Journal of linguistic anthropology, vol. 9, no. 1, 1999, pp. 111-114.

[8] D. Larsen-Freeman and L. Cameron, Complex systems and applied linguistics, Oxford, UK: Oxford University Press, 2007.

[9] J. Creswell, Qualitative inquiry and research design: Choosing among five approaches, CA: Sage, 2007.

[10] F. M. Connelly, D. J. Clandinin, "Stories of experience and narrative inquiry," Educational Researcher, vol. 19, no. 5, 1990, pp. 2-14.

[11] S. Trahar, Contextualizing narrative Inquiry: developing methodological approaches for local contexts, Hoboken: Taylor and Francis, 2013.

[12] D. Clandinin, J. Rosiek, Mapping a Landscape of Narrative Inquiry: Borderland Spaces and Tensions, in: Proceedings of Handbook of narrative inquiry: Mapping a methodology, Sage Publications, Inc., 2017, pp. 35-75.

[13] J. Miller, Audible differences: ESL and social identity in schools, Clevendon: Multilingual Matters, 2003.

[14] F. M. Connelly and D. J. Clandinin, Narrative 
Inquiry, in Handbook of complementary methods in education research, New Jersey, Lawrence Erlbaum Asc. Inc., 2006, pp. 447-488.

[15] D. Block, Second language identities, London: Continuum, 2007.

[16] B. Norton, K.Toohey, Identity, language learning, and social change, in: Proceedings of Language Teaching, vol. 44, no. 4, 2011, pp. 412-446.

[17] E. Wenger, Communities of practice and social learning systems, in: Proceedings of Organization, vol. 7, no. 2, 2000, pp. 225-246.

[18] Y. Kanno, B. Norton, Imagined communities and educational possibilities: Introduction, in: Proceedings of Journal of Language, Identity, and Education vol. 2, no. 4, 2003, pp. 241-250. 